\title{
The Manufacture and Nutritional Analysis of the Nelumbonucifera Jam With Material properties
}

\author{
Guo $\mathrm{Hu}^{1}$ Shangqin $\mathrm{Hu}^{2}$ \\ ${ }^{1}$ College of Fine Arts, Chongqing Normal University, Chongqing, China \\ ${ }^{2}$ College of Life Science Chongqing Normal University, Chongqing ,China \\ ae-mail: ennhu@163.com, ahushangqin@163.com
}

Keywords : Nelumbonucifera ; jam ; nutrition ; process; analysis

\begin{abstract}
In order to further develop the use of Nelumbonucifera and carry on the intensive processing to the Nelumbonucifera,use the Nelumbonucifera entity as the raw material. After cleaning and grinding into the sauce and mixing with the supplementary material ,the bottling sterilization becomes the Nelumbonucifera jam, and making the nutrition ingredient analysis separately to the Nelumbonucifera jam with chemistry method and the instrument method .The result indicates that the Nelumbonucifera jam color is bright and light red brown ,flavor tasty ,the nutrition is rich ,the protein content is $3.27 \%$, including 17 kinds of amino acids and the 8 kinds of essential amino acids of the human body, the fat is $1.15 \%$, as well as the rich mineral substance, with the vitamin .The Nelumbonucifera jam is one of the nutrition for the old and seasiongs young. This has provided the scientific basis for the Nelumbonucifera thorogh research and the development.
\end{abstract}

\section{Introduction}

The Nelumbonucifera is Nymphaeaceae years of aquatic herbs.It originally grows in China , India[1], the Malay peninsula and other places on the marsh area , and it has 3000 years'growing history in our country. There are good prospects of marketplace in the international and internal. As a result of the nourishing, high output, good storage of the lasting long, it is also an important traditional Chinese medicine. The Nelumbonucifera has formed good breed in Zhejiang, The planting area of 2000000 acres,yielded per mu 3500Kg [2, 3].Although there are various edible methods, yet there is a feeling of the indigestion. so the consumption is of the Nelumbonucifera is limited. There is no research report of the Nelumbonucifera in the document means of the examination .The purpose of the research is to use Nelumbonucifera to process Nelumbonucifera jam ,This way not only retained nutrition and special flavour, but also provided the need for the market, and that is a new type of flavouring with the colours, sweet smell for the grown-ups and children. This has provided the Nelumbonucifera thorogh research and the development

\section{Materials and methods}

\section{Materials.}

Nelumbonucifera: Nelumbonucifera stem tuber is purchased from free market of Shapingba.

Reagents : Gln, Ala ,Gly, Leu, Ileu, Arg, Lys, Thr, Val, Phe , Tyr , His , Asp, Ser, Try , Vitamin A, Vitamin B1 ,B2 , B5 , B6 , B11, B12, Vitamin C , beef extract ,peptones ,NaclL, $\mathrm{H} 2 \mathrm{SO} 4, \mathrm{HCL}, \mathrm{K} 2 \mathrm{SO} 4$ and so on .

Instrument equipment: fat draw appearance, KJELTEC2300 protein analyse appearance, UV-9100 ultraviolet spectrometer, JJ-2 mould tissue pound to pieces machine, Aas vario 6 mould amino acid automatic analyse appearance, Atom absorb spectrometer, Soxtec Avanti 2055 fat analyse appearance, Air be overanxious work table, Sterile room, Hot-air sterilizer, Autoclave and so on .

Methods

Technical process. Nelumbonucifera Raw material $\rightarrow$ Elimination belt putty and insect pest part $\rightarrow$ Cleaning silt $\rightarrow$ Steam boiling block stem $\rightarrow$ Putting it in the grinder and add $50 \%$ water, beating $\rightarrow$ Adding supplementary materials such as 
salt ,etc. $\rightarrow$ Bottling $\rightarrow$ Pasteurization $\rightarrow$ Spot-check $\rightarrow$ Warehousing.

Nelumbonucifera jam processing technology: The block stem has much clay on it due to its growth in the soil .So, before the processing Clay must be remove. After removal of the skin and completely cleaning, then steam boiling carries on the beating again, and add the right amount of water (50\%) for the beating, the thick liquid should be as tiny as possible.In the processing,the clean and healty environment is required(to carry on in sterile room), the beater and each kind of apparatus, the vessel should be disinfected first. Add the table salt $8-12 \%$, the Chinese prickly ash $1 \%$, the hot pepper $5-8 \%$, helps the fresh medicinal preparation $1 \%$, the ginger $6-8 \%$, the vegetable oil $2-5 \%$ to the thick liquid and make it even. After the bottling for the quality the Pakistan disinfection and the spot-check, going into storage, under the low temperature or the normal temperature presevation.

Nelumbonucifera jam nutrition ingredient analysis determination method: Determines the protein content with the KJELEC2300protein analyzer.Determines the fat content with the Soxtec Avanti 2055 fat instrumentation law[4]. Determines the Vitamin with the liquid chromatography capacity law[4].Determines the amino acid content with the Hitachi L- 880 amino acid autoanalyzers[4]. Absorbs the spectrophotometer law determination mineral substance with the Hitachi Z-5000 atoms the content[4]. Determines the carbohydrate content with the capacity law[4]. Determines the color fragrance with the sense organ law[5].

\section{Results and Discussion.}

Nelumbonucifera jam nutrition ingredient analysis. Nelumbonucifera jam According to Li Heng, Wang Jirang, the Qu Ming Xun food sense organ appraisal method carries on the sense organ appraisal, its nutrition is rich, the flavor is tasty, the color fragrance body is complete, in which protein, the fat, the carbohydrate, the cellulose content analysis, finally see Table 1 and Figure 1.

Table 1 In Nelumbonucifera jam main nutrition ingredient content

\begin{tabular}{lccc}
\hline component name & $\begin{array}{c}\text { In jam content }) \\
(\mathrm{g} / 100 \mathrm{~g})\end{array}$ & $\begin{array}{l}\text { In raw material conte } \\
(\mathrm{g} / 100 \mathrm{~g})\end{array}$ \\
\hline Crude protein & 3.27 & & 1.21 \\
crude fat & 1.15 & & 0.13 \\
carbohydrate* & 17.04 & 16.94 \\
crude fiber element & 1.17 & 0.65 \\
\hline
\end{tabular}

*Mainly is the starch

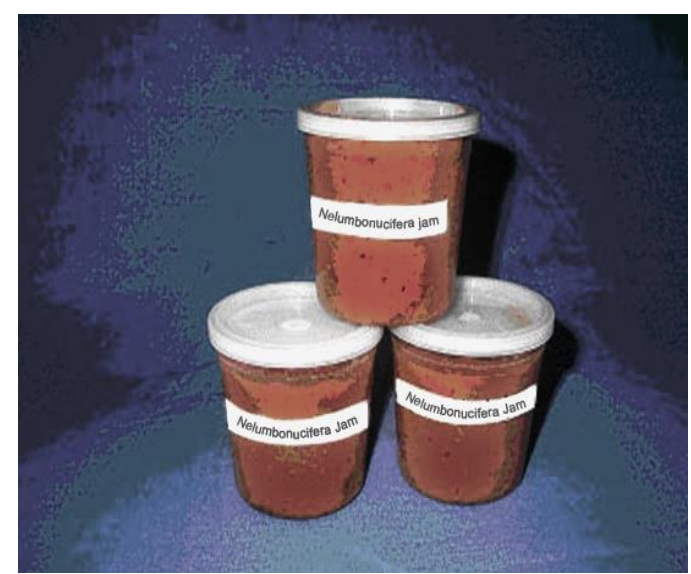

Fig. 1 Nelumbonucifera jamProduct

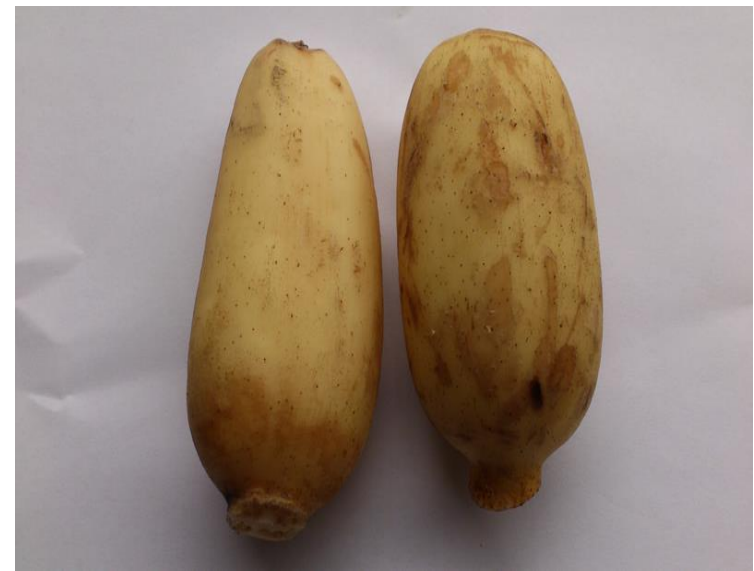

Nelumbonucifera Materials 
We may the Resul see from Table 1, in the Nelumbonucifera jam the protein content $3.27 \%$, the fat $1.15 \%$, the carbohydrate $17.04 \%$, in the cellulose $1.17 \%$. showing sauces the nutrition is rich, The protein is the main nutrition essential factor which the human body needs, it is closely linked with the vital activity, does not have the protein existence, any vital activity is unimaginable, the life is the protein existence way.

In the Nelumbonucifera jam amino acid type and content analysis. With the Hitachi L- 8800 amino acid autoanalyzer determination Nelumbonucifera jam in the amino acid type and the content, finally see Table 2 .

Table 2 Nelumbonucifera jam In sauce amino acid content

\begin{tabular}{lccccc}
\hline $\begin{array}{c}\text { Serial } \\
\text { Number }\end{array}$ & $\begin{array}{c}\text { component } \\
\text { name }\end{array}$ & $\begin{array}{c}\text { content } \\
(\mathrm{mg} / 100 \mathrm{~g})\end{array}$ & $\begin{array}{c}\text { Serial } \\
\text { Number }\end{array}$ & $\begin{array}{c}\text { component } \\
\text { name }\end{array}$ & $\begin{array}{c}\text { content } \\
(\mathrm{mg} / 100 \mathrm{~g})\end{array}$ \\
\hline 1 & Ile & 49.54 & 10 & Asn & 179.49 \\
2 & Thr & 47.69 & 11 & Ser & 48.45 \\
3 & Leu & 72.70 & 12 & Tyr & 27.46 \\
4 & Phe & 76.67 & 13 & Glu & 572.50 \\
5 & Lys & 48.33 & 14 & Gly & 51.35 \\
6 & Ala & 56.09 & 15 & His & 49.58 \\
7 & Cys-Cys & 28.30 & 16 & Arg & 153.90 \\
8 & Val & 65.22 & 17 & Pro & 60.20 \\
9 & Met & 24.70 & & & \\
\hline
\end{tabular}

We may see from Table 2, in the Nelumbonucifera jam the amino acid is complete.It contains 17 kinds of amino acids, 8 kind of human body essential amino acids, this is one kind of new complete amino acid seasoning.

In the Nelumbonucifera jam Vitamin content analysis. In the serial number Nelumbonucifera jam Vitamin content after the liquid chromatography volumetric determination determination, finally see Table 3.

Table 3 in the Nelumbonucifera jam Vitamin content.

Component name content. $(\mathrm{mg} / 100 \mathrm{~g}) \quad$ Component name content. $(\mathrm{mg} / 100 \mathrm{~g})$

\begin{tabular}{lcccc} 
Vitamin A & & 0.04 & Vitamin C & 38.01 \\
Vitamin pp & 0.26 & Vitamin $\mathrm{B}_{2}$ & 0.02 \\
Vitamin $\mathrm{B}_{3}$ & 0.02 & Vitamin $\mathrm{B}_{1}$ & 0.07 \\
\hline
\end{tabular}

From Table 3, in the Nelumbonucifera jam Vitamin content is quite rich, in which Vitamin $\mathrm{C}$ content is highest, for $38.01 \mathrm{mg} / 100 \mathrm{~g}$, next is the nicotinic acid amide for $0.26 \mathrm{mg} / 100 \mathrm{~g}$ and Vitamin B1 is $0.07 \mathrm{mg} / \mathrm{g}$.The Vitamin is one of six big essential nutrition human body need factors, and is an important nutritious ingredient for health. If the human body lacks some kind of Vitamin for a long time ,it is possible to cause this kind of Vitamin the model deficient symptom. So,the human body must have enough quantity of the Vitamin, and guarantee organism the normal physiological function need.The Nelumbonucifera jam is satisfactory for this requirement.

In the Nelumbonucifera jam mineral substance content analysis. The Nelumbonucifera jam after the Hitachi Z-5000 atom absorption spectrophotometer law analysis, its mineral substance content, see Table 4. 
Table 4 In the Nelumbonucifera jam mineral substance content

\begin{tabular}{cc}
\hline Mineral prime abbreviation & content $(\mathrm{mg} / 100 \mathrm{~g})$ \\
\hline $\mathrm{K}$ & 243.00 \\
$\mathrm{Mn}$ & 1.30 \\
$\mathrm{C}_{\mathrm{a}}$ & 32.60 \\
$\mathrm{M}_{\mathrm{g}}$ & 19.0 \\
$\mathrm{~F}_{\mathrm{e}}$ & 2.60 \\
$\mathrm{Cu}$ & 0.11 \\
$\mathrm{Z}_{\mathrm{n}}$ & 0.23 \\
$\mathrm{Na}$ & 44.20 \\
$\mathrm{P}$ & 61.70 \\
\hline
\end{tabular}

Table 4 indicated that in the Nelumbonucifera jam the mineral substance type is complete. The $\mathrm{K}, \mathrm{Ca}, \mathrm{Mg}, \mathrm{Fe}, \mathrm{Zn}$ content is rich.They all are essential elements for the symptom. The potassium content is highest $(243.0 \mathrm{mg} / 100 \mathrm{~g})$, the potassium can promote the human body cahuman body. The calcium content high for $32.6 \mathrm{mg} / 100 \mathrm{~g}$, it is most important in the human body and organism, the calcium is essential mineral element of the body. If the human body lacks the calcium,it is possible to cause rickets and the osteoporosis rdiac muscle activity, and certain curative effect on the hypertension sickness and feeble heart as well. The zinc is the extremely important element this. The Zinc content is $0.23 \mathrm{mg} / 100 \mathrm{~g}$, it is some enzymes the accessory factor, lacks of the iron will be able to cause the poor hemopathy. Therefore, mineral substance and calcium, iron, zinc, potassium,etc. are playing the vital rolein the human body, is the present people to the food middling material element research important content, also is the people weighs one of food nutrition important symbols. The Nelumbonucifera jam in this aspect is the seasoning which is characteristic .

\section{Conclusion}

The findings indicated that, the Nelumbonucifera jam manufacture craft is simple, the cost is low, does not need the expensive specific installation, is advantageous in the Nelumbonucifera jam production processing technology promotion and the Nelumbonucifera jam development intensive processing. In the sauce the nutrition is rich, the amino acid is complete, including 17 kind of above amino acids and the human body 8 kind of essential amino acids, the protein content $3.27 \%$, fat content $1.15 \%$, cellulose content $1.17 \%$, carbohydrate content $17.04 \%$. Vitamin C quite is specially high for $38.01 \mathrm{mg} / 100 \mathrm{~g}$, the potassium, the calcium, the iron, the zinc content are rich, respectively is $243.00 \mathrm{mg} / 100 \mathrm{~g}, 32.60 \mathrm{mg} / 100 \mathrm{~g}, 2.60 \mathrm{mg} / 100 \mathrm{~g}, 0.23 \mathrm{mg} / 100 \mathrm{~g}$. Moreover the flavor is tasty, it is easy to digest, enhances the nutrition the use factor, and also eliminated Nelumbonucifera the general edible method to cause the inflation shortcoming. It is one kind concurrently suitable nutrition rich newest seasoning for the old and young .

\section{References}

[1].Biology department of the Shanghai Normal University, Shanghai Normal College, Chinese Academy of Sciences Shanghai Physiological Institute, Dictionary (Biological Sciences), the Shanghai dictionary press, 1978, p190-227 (in Chinese )

[2] Yang Xuejun,outlook of value and foreground of processing of Nelumbonucifera cultivation[J], scientific pisciculture,2002(7):56-57 (in Chinese )

[3].Mei Zaisheng, cultivation techniques for Nelumbonucifera [J], Chinese agricultural information, 2007(11):21-23 (in Chinese ) 
[4].HUANG Wei-kun . Food examines and analyzes [M], Beijing, the light industry publishing house, 1989,17-705 (in Chinese )

[5].LI Heng,WANG Ji-rang, QU Ming-xun . Food sense organ appraisal method and practices

[M], Shanghai Science and technology Literature Publishing house, 1990,116-141 (in Chinese ) 